\title{
Validity of Rational Addiction Model for Cinema Demand in Turkey
}

\author{
Volkan KAYMAZ*
}

\begin{abstract}
This study examines the demand for cinema in Turkey using economic and other explanatory variables. The study includes annual data for the period 2009-2017 on 26 sub-regions of Turkey and a dynamic panel data analysis was performed. Furthermore, the validity of the rational addiction model developed by Becker and Murphy (1988) has been investigated for the Turkish cinema market and the role of addiction in cinema demand has been discussed. Estimation results from the dynamic panel data model show that the number of screen and the share of domestic films in total films are an important component in explaining cinema demand. Furthermore, the results showed that the demand for cinema is compatible with the rational addiction model.

Keywords: Cinema demand, Cultural economics, Rational addiction model, Panel data, Sub-regions

\section{Rasyonel Bağımlılık Modelinin Türkiye'deki Sinema Talebi İçin Geçerliliği}

Öz

$\mathrm{Bu}$ çalışma, Türkiye'deki sinema talebini, ekonomik ve diğer açıklayıcı değişkenleri kullanarak incelemektedir. Çalışmada, Türkiye'nin 26 alt bölgesine ilişkin 2009-2017 dönemi yıllık verileri kullanılmıştır ve dinamik panel veri analizi gerçekleștirilmiștir. Ayrıca Becker ve Murphy (1988) tarafından geliştirilen rasyonel bağımlılık modelinin geçerliliği Türkiye sinema sektörü için araștırılarak, sinema talebinde bağımlılığın rolü ele alınmıştır. Dinamik panel veri modelinden elde edilen tahmin sonuçları, ekran sayısının ve yerli filmlerin toplam filmler içerisindeki payının, sinema talebini açıklamada önemli bir bileşen olduğunu göstermektedir. Ayrıca sonuçlar, sinema talebinin rasyonel bağımlılık modeline uyumlu olduğunu göstermiştir.

Anahtar Kelimeler: Sinema talebi, Kültürel ekonomi, Rasyonel bağımlılık modeli, Panel veri, Türkiye illeri
\end{abstract}

\section{Introduction}

Cinema is one of the most popular artistic activities due to its easy access and reasonable prices. Although the demand for cinema has fluctuated over time, the sector

\section{Özgün Araștırma Makalesi (Original Research Article) \\ Geliş/Received: 14.02 .2020 \\ Kabul/Accepted: 26.08 .2020 \\ DOI: https://dx.doi.org/10.17336/igusbd.681434}

${ }^{*}$ Asst. Prof. Dr., Istanbul Yeni Yuzyil University, Faculty of Economics and Administrative Sciences, Istanbul, Turkey, E-mail: volkan.kaymaz@yeniyuzyil.edu.tr ORCID https://orcid.org/0000-0001$\underline{7556-9507}$ 
has managed to survive. The change of the demand for cinema over the years is due to many reasons. Besides economic and demographic variables, technology is also an important factor. Although the alternatives to cinema in the entertainment industry have increased over time, online streaming services and movie rental services have started to be used more, cinema has managed to preserve its existence. For this reason, various authors have been questioned whether cinema is an addictive product and studies investigating this subject have been conducted.

The rational addiction model developed by Becker and Murphy (1988) was used for addictive products like cigarette, but it was also applied to the cinema sectors of various countries by other authors. Rational addiction model, which has not been applied for the Turkish cinema market before, is the main question of this study. The aim of this study is to investigate the factors that affect the demand for cinema and to investigate whether cinema demand is appropriate for rational addiction model.

This paper is organized as follows. Section 2 provides general information about the cinema market in Turkey. Section 3 provides a brief summary of existing empirical literature. Section 4 describes the data and econometric methodology. Section 5 presents the empirical results. Section 6 provides the summary and conclusions.

\section{Cinema Attendance in Turkey}

After the end of the Second World War, cinema demand in European countries and Turkey have increased rapidly. 247 million tickets sold in 1970, which is a record demand for cinema in Turkey (Kanzler, 2014, 16). With the widespread use of television, the demand for cinema decreased after 1970s and started to increase again in European countries in the 1990s. The number of tickets sold per person increased from 1.68 in 1990 to 2.47 in 2002 (Dewenter \& Westermann, 2005, 213). In Turkey, the number of tickets sold per person in 2002 was 0.23 . With this low value, the government has decided to support local filmmakers since the mid-2000s, and the Turkish Cinema Market has revived and started to bring more films to the audience. Despite this increase, few domestic films have managed to attract a high number of audiences. Of the 357 feature films that were released in 2014, only 14 exceeded one million audiences (Tomur et al. 2016, 24).

Figure 1: Number of Attendance 2000-2018

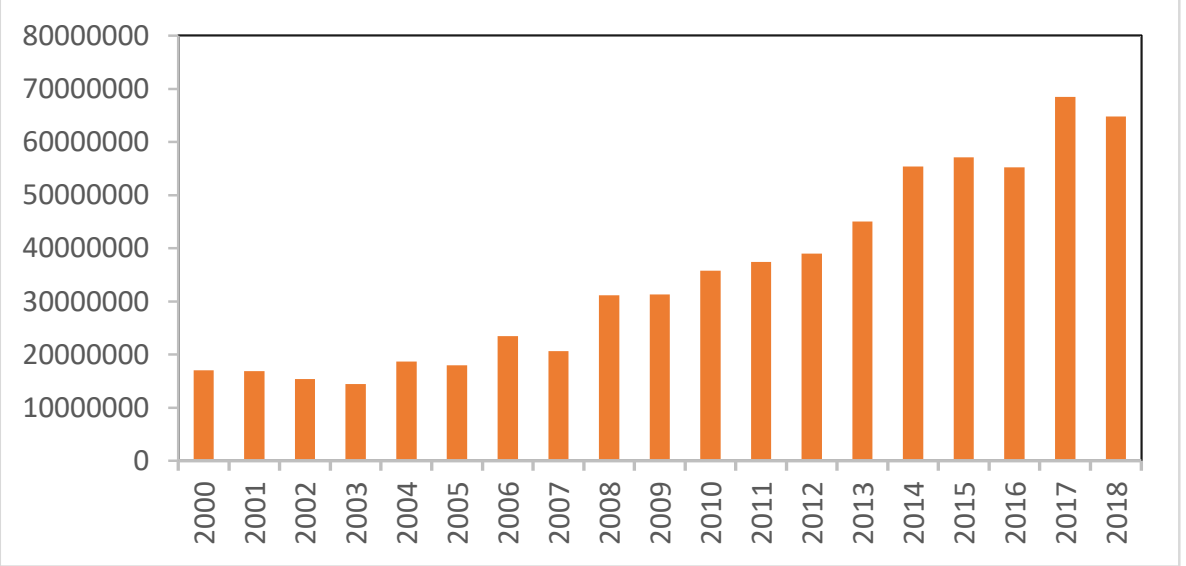

Source: The Turkish Statistical Institute 
Although there have been fluctuations in the total number of audience since the mid-2000s, the change was generally upward. While many factors have played a role in changing the demand for cinema, cinema itself has also changed over time. Today, cinema has become quite different from what it was in the 1960s and 1970s. With the emergence of cinema complexes with multiple halls, structural changes have taken place in the cinema industry (Cuadrado \& Frasquet, 1999). Generally, multi-theaters cinemas started to serve in shopping malls. The increase in the number of shopping centers has made the cinema more accessible. It is easier to attract people who come to the mall for shopping, to the cinema.

Multi-theaters cinemas have created a new demand for cinema. The increase in shopping malls has led to the opening of cinemas not only in city centers but also in other neighborhoods (Hubbard, 2002). Thus, the increase in supply has provided the elimination of previously unmet demand (Collins, Hand, Ryder 2005).

Figure 2. Cinema Attendance in Turkish provinces in 2017
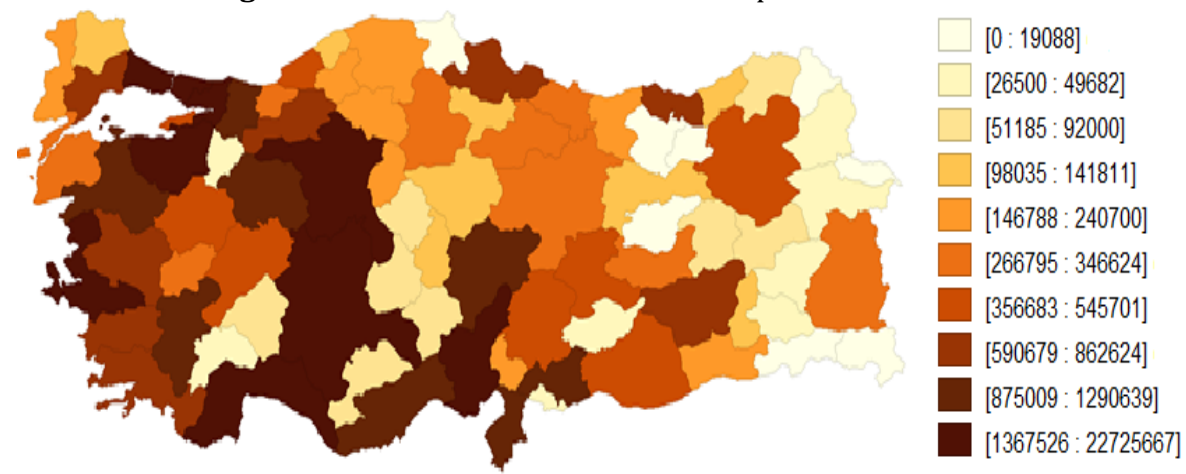

Source: It was created in the GWR4 program by the author using TURKSTAT data.

In terms of cinema attendance in Turkey shows regional differences. This difference lies at the level of regional development and cinema supply. The 2017 data shows that cinema attendance is steadily declining as it moves eastward.

\section{Literature Review}

There are few studies in the literature examining the validity of the demand for cinema to the rational addiction model.

In their study using data from Spain, Blanco and Pino (1997) used cointegration analysis to estimate the individual cinema demand function. In the study, which used annual data between 1968 and 1992, ticket prices, income and the use of television were determined as the variables affecting the amount of cinema attendance. The results showed that cinema has the characteristics of luxury good and that demand for cinema is elastic in terms of price. In addition, although income positively affects cinema attendance, the increase in television programs significantly reduces the demand for cinema.

Cameron (1999) tested the adaptation of cinema demand in the United Kingdom to the theory of rational addiction model with cross-sectional data from 1965 to 1983. The effects of ticket price, real income, number of cinema screens and the effect of color television as dummy variable showed that rational addiction model does not appropriate to cinema. 
Sisto and Zanola (2004) adapted the rational addiction model developed by Becker and Murphy (1988) to the cinema sector in 13 European countries. In this study, panel data and time series data were used. The results of the generalized moments method (GMM) showed that cinema is in accordance with the rational addiction model. In addition, the results of the analysis showed that income, number of screens and number of movies positively affected the demand for cinema and ticket prices moved in the opposite direction with the demand for cinema.

Dewenter and Westermann (2005) analyzed cinema attendance in Germany between 1950 and 2002 using the 2SLS technique. The study which shows the long-term relationship between real income and price variables, reveals that the increase in the number of domestic movies positively affects the demand for cinema. In the study where the price elasticity of demand is between -2.40 and -2.47 , the income elasticity was found to be less than 1 and it was significant that cinema cannot be considered as a luxury good. Therefore, it was revealed that the demand for cinema was not addictive.

Yamamura (2008), which investigated the revival process of the cinema industry in Japan, used the fixed effects method with panel data of 47 provinces between 1990 and 2001. In his study, he used data on the number of attendance to cinema, ticket prices, number of screens, number of screens in shopping malls, the ratio of the number of domestic movies to the total number of movies, total population, population density, real income, population between the ages of 20-24 and over 60 years. The results of the analysis showed that the increase in ticket prices had a negative effect on the demand for cinema and the number of shopping malls and screens changed in the same direction with cinema attendance. Fixed effects and fixed effects 2SLS estimators showed that the increase in ticket prices negatively affected the demand for cinema, and a $1 \%$ increase in multiple screened movie theaters increased cinema attendance by $0.2 \%$. On the other hand, the increase in the number of domestic movies released in Japan has a negative impact on cinema attendance, so it is understood that foreign movies are more popular in the country and that the per capita income moves in the opposite direction with cinema attendance, therefore, cinema exhibits an inferior good property. Among the demographic variables, the population between $20-24$ and over 60 years had a positive effect on the demand for cinema.

In 2009, Yamamura tested the rational addiction model of Becker and Murphy (1988) using panel data from 47 Japanese provinces between 1994 and 1998, using lagged and leading indicators in the number of cinema attendance and ticket prices. In the study, two-stage least squares (2SLS) and two-stage least squares with error components (EC2SLS) were used for estimation. The results showed that the lagged and leading indicators of the number of cinema attendance had a positive effect on cinema attendance, the price variable and the leading price indicator had positive signs and the lagged price indicator had negative signs. Therefore, Yamamura (2009) stated that the results are consistent with the rational addiction model. In terms of age groups, when the age increases, the adaptation of the demand for cinema to the rational addiction model increased; however, the lack of compatibility for the model for young people is explained by the argument that they are turning to alternative options instead of cinema.

Dessy and Gambaro (2009) discuss the development of 15 European countries' cinema demand between 1989 and 2003. With the number of tickets per person, national income per capita, ticket prices, number of screens, number of people per screen and number of people per seat, analyzed with random effects and fixed effects estimators. In this study, cross section data and time series data were used. As expected, cinema attendance moves in the same direction with the gross domestic product per capita, number of multi-screen theater and the number of seats. The price negatively affects the demand for cinema. The elasticity coefficient of 0.37 per capita income shows that cinema 
is not a luxury good. According to the LSDVC estimation results, the coefficient on the onetime lagged dependent variable is not even significant at any conventional level.

There is no full agreement between the studies that test the validity of the demand for cinema with the rational addiction model. The factors affecting cinema demand and cinema attendance vary from country to country and from period to period. Therefore, it would not be correct to say that it is an addictive product for cinema in every country or region. While studies show that the demand for cinema moves in the same direction with the increase of real income and cinema screen in general, the increasing digitalization in recent years has caused cinema to become a niche product with the widespread of online movie rental services and the increase of online stream subscriptions. For this reason, the change in real income and prices does not adapt on cinema attendance as much as expected.

\section{Econometric Models and Data}

A standard inter sub-region panel data model was used to examine the relationship between cinema demand, economic and other variables, including both time invariant sub-region fixed-effects and sub-region invariant time effects. The model can be written as:

$$
\operatorname{ATTEN}_{i t}=\alpha+\beta T_{i t}^{\prime}+\theta^{\prime} X_{i t}+\eta_{i}+\lambda_{t}+u_{i t}
$$

$A T T E N_{i t}$ stands for cinema participation in the time period $t$ for the sub-region i., $T_{i t}$ is the ticket price, $X_{i t}$ the vector of the control variables, $\eta_{i}$ is the sub-region constant effects, $\lambda_{t}$ is the time constant effects and $u_{i t}$ is the idiosyncratic error term. The model presented in equation (1) is static. Considering that cinema attendance may change over time, the following dynamic specification is required.

$$
\text { ATTEN }_{i t}=\alpha+\rho A \text { TTEN }_{i, t-1}+\beta^{\prime} T_{i t}+\theta^{\prime} X_{i t}+\eta_{i}+\lambda_{t}+u_{i t}
$$

The dynamic model allows robustness control of the fixed effects model by allowing the lagged dependent variable to be an explanatory variable. In addition to these arguments, the lagged attendance can also be viewed as a proxy for unobserved subregion effects.

\subsection{Rational Addiction Model}

Becker and Murphy (1998) developed the theory of rational addiction considering that consumers are dependent on certain products. According to the theory, past consumption of some goods affects the marginal utility of current and future consumption (Becker et al. 1994, 396). According to the model, even if people know that the product, they consume is addictive, they continue their activities by evaluating the individual benefits they obtain from the product. Past consumption of the individual increases the marginal benefit of current consumption.

Becker et al. (1994) chose a physically addictive, harmful product such as cigarette to examine the validity of rational addiction theory. They included the current price of cigarette, past and future consumption into the model to test the role of addiction in cigarette consumption. The validity of this theory for cinema was first applied by Cameron (1999). The theory was tested for different goods and products over time and cinema was one of them. 


$$
\text { ATTEN }_{i t}=\alpha+\rho \operatorname{ATTEN}_{i, t-1}+\sigma \operatorname{ATTEN}_{i, t+1}+\beta^{\prime} T_{i t}+\theta^{\prime} X_{i t}+\eta_{i}+\lambda_{t}+u_{i t}
$$

\subsection{Data}

In this study, panel data of 26 sub-regions of Turkey between the years 2009-2017 were used. The sources of the data used in the study are included in the Appendix 1 . The cinema attendance $\left(A T T E N_{i t}\right)$ data is based on the number of movie tickets sold each year. As in the economic related variable, price of ticket is added to model. Gross domestic product per capita was used to analyze the impact of revenue on cinema demand. In order to see the effect of the number of domestic movies on the demand for cinema, the share of domestic movies in the total movies is added to the data set at each sub-region level. In addition, the number of shopping malls and the number of cinema screens in operations has been added to the model. The logarithm of all variables was taken except for the ratio of domestic films in total films and shopping mall. Summary information about the data is included in Appendix 2.

\section{Estimation Results}

Our empirical results are organized as follows. First, the results of the fixed effects method, which is applied considering the Hausman test results, are shown in Table 1. After the results of dynamic GMM estimation are shown in Table 2, the validity of cinema to the rational addiction model is discussed according to Table 3 . All formulations include time dummies. Time and sub-region effects are all statistically significant in all results.

\subsection{Static Fixed-Effects Estimation Results}

Table 1 presents the results of Hausman Test and fixed effect estimation. The Hausman test is used in applied economic work as a test of misspecification (Chmelarova, $2007,5)$. Hausman Test result indicates rejection of the null hypothesis of uncorrelated time-invariant unobserved heterogeneity with the regressors therefore we can conclude that the fixed effects model is better to choose.

GDP per capita income and screen variables are statistically significant and positively signed. We expect about $1 \%$ increase in attendance score when gdp per capita increase by $1 \%$. The coefficient of domestic movie ratio exhibits negative and significant impact on cinema attendance. The number of screen is significant at the $5 \%$ level. A $\% 1$ increase in the screen leads to about $0.6 \%$ increase in attendance. Shopping mall has negative and significant at the 5\% level. A one-point increase in the shopping mall leads to about $0.01 \%$ increase in cinema attendance. Price and domestic movie ratio are insignificant in the model. 


\begin{tabular}{|l|l|l|}
\hline Variables & $\begin{array}{l}\text { Estimated } \\
\text { Coefficient }\end{array}$ & $\begin{array}{l}\text { Standard } \\
\text { Errors }\end{array}$ \\
\hline Price & -0.498 & $(0.292)$ \\
\hline GDP Per Capita & $1.097^{* * *}$ & $(0.171)$ \\
\hline $\begin{array}{l}\text { Domestic Movie } \\
\text { Ratio }\end{array}$ & -0.338 & $(0.230)$ \\
\hline Shopping Mall & $-0.012^{* *}$ & $(0.004)$ \\
\hline Screen & $0.618^{* * *}$ & $(0.084)$ \\
\hline Constant & 1.926 & $(1.032)$ \\
\hline Number of Groups & 26 & \\
\hline N & 234 & \\
\hline$R^{2}$ & 0.882 \\
\hline F-Time & 0.000 \\
\hline F-Sub-Region & 0.000 & \\
\hline Hausman Test & 34,29 & 0.0000 \\
\hline Wooldridge Test & 22,996 & 0.0001 \\
\hline Wald test & 1742,62 & 0.0000 \\
\hline
\end{tabular}

Table 1: Static Fixed-Effects Estimation Results

Note: F-Time and F-Sub-Region are the p-values from the F-test of time effects and subregion effects, respectively. Significance levels for asterisks: *10\%; ${ }^{* *} 5 \%$; ${ }^{* *} 1 \%$.

\subsection{Dynamic GMM Results}

Table 2 summarizes the dynamic system GMM estimation results for the cinema attendance. The use of the lagged dependent variable in the model causes the problem of endogenity. The fixed-effects estimator is biased and inconsistent in small $\mathrm{T}$ large $\mathrm{N}$ panels. Therefore, in addition to the fixed effects estimator, the system GMM estimator developed by Richard Blundell and Stephen Bond (1998) is used in the study.

In the study is reported the AR (2) test of Arellano and Bond (1991) for the validity of instruments and moment conditions. AR(2) test show no evidence of autocorrelation at conventional levels of significance. We also reported the Hansen Test results. The Hansen test indicates that the null hypothesis that moment conditions are correctly specified cannot be rejected. Together with the AR(2) test, we can conclude that moment conditions are valid and model does not have a serial correlation problem.

\begin{tabular}{|l|c|c|}
\hline \multicolumn{1}{|c|}{ Variables } & $\begin{array}{c}\text { Estimated } \\
\text { Coefficient }\end{array}$ & $\begin{array}{c}\text { Standard } \\
\text { Errors }\end{array}$ \\
\hline Lagged Attendance & 0.055 & $(0.146)$ \\
\hline Price & -0.195 & $(0.386)$ \\
\hline GDP Per Capita & 0.079 & $(0.187)$ \\
\hline $\begin{array}{l}\text { Domestic Movie } \\
\text { Ratio }\end{array}$ & $-2.681^{* * *}$ & $(0.514)$ \\
\hline Mall & 0.001 & $(0.002)$ \\
\hline Screen & $0.904^{* * *}$ & $(0.179)$ \\
\hline Cons & $10.62^{* * *}$ & $(1.970)$ \\
\hline Number of Obs & \multicolumn{2}{|c|}{25} \\
\hline N & \multicolumn{2}{|c|}{206} \\
\hline $\begin{array}{l}\mid 2 \\
\text { Number of }\end{array}$ & \multicolumn{2}{|c|}{21} \\
\hline nnstruments & \multicolumn{2}{|c|}{0.273} \\
\hline AR (2) test (pval) & \multicolumn{2}{|c|}{0.277} \\
\hline Hansen test (pval) &
\end{tabular}

Table 2: Dynamic System GMM Estimation Results Note: Significance levels for asterisks: ${ }^{*} 10 \% ;{ }^{* *} \%$; ${ }^{* * *} 1 \%$. 
The results in Table 2 indicate that the lagged attendance is statistically insignificant in the model. As can be seen in Table 2, none of the variables, except domestic movie ratio and screen, is significant. The domestic movie ratio has a significant negative effect on cinema attendance but screen has a positive effect on cinema attendance.

In literature, the effect of income on movie demand is not clear. All the authors, except Yamamura (2008), have reached a positive relationship between income and movie demand. In our results, per capita income is statistically insignificant. When the effect of ticket prices on the cinema demand is examined, Blanco and Pino (1997) indicate that cinema demand in Spain, measured by attendance per inhabitant, is elastic with regard to its price. This unexpected relationship between price and demand can be explained by the number of cinema tickets per person in Turkey. Compared to European countries, the demand for cinema in Turkey, the ticket prices being too low, which limits the relationship between cinema demand and prices. Estimation results show that the number of screens moves in the same direction as cinema demand. This result is supported by the fact that there are few movie theaters in Turkey except for the populated cities. Finally, similar to the results of Yamamura (2008), the increase in the number of domestic films surprisingly reduces the interest in cinema. This result is consistent with the low audience number of domestic films in Turkey.

\subsection{Rational Addiction Model Estimation Results}

Table 3 presents the result of rational addiction model estimation results. Lagged Attendance is again statistically is insignificant but lead attendance is statistically significant (although only at the $10 \%$ significance level). Other variables received similar results to Table 2 .

The estimation results provide an evidence that cinema consumption conforms to a rational addiction hypothesis. Our results are consistent with the work of Sisto and Zanola (2004) and Yamamura (2009), but not with Cameron (1999) and Dewenter and Westermann (2005). In the literature, there is no clear consensus on the adaptation of cinema demand to the rational addiction model; cinema is accepted as luxury goods in some countries and inferior goods in other countries. This different perception of cinema leads to the rational addiction theory giving different results according to countries.

\begin{tabular}{|l|l|l|}
\hline Variables & $\begin{array}{l}\text { Estimated } \\
\text { Coefficient }\end{array}$ & $\begin{array}{l}\text { Standard } \\
\text { Errors }\end{array}$ \\
\hline Lagged Attendance & 0.226 & $(0.208)$ \\
\hline Lead Attendance & $0.133^{*}$ & $(0.050)$ \\
\hline Price & -0.124 & $(0.337)$ \\
\hline GDP Per Capita & 0.043 & $(0.020)$ \\
\hline $\begin{array}{l}\text { Domestic Movie } \\
\text { Ratio }\end{array}$ & $-1.694^{* * *}$ & $(0.371)$ \\
\hline Mall & 0.001 & $(0.002)$ \\
\hline Screen & $0.625^{* *}$ & $(0.214)$ \\
\hline Cons & $7.388^{* * *}$ & $(1.558)$ \\
\hline Number of Cities & 26 & \\
\hline N & 205 & \\
\hline $\begin{array}{l}\text { Number of } \\
\text { Instruments }\end{array}$ & 22 \\
\hline AR (2) test (pval) & 0.390 \\
\hline Hansen test (pval) & 0.061 \\
\hline
\end{tabular}

Table 3: Rational Addiction Model Estimation Results

Note: Significance levels for asterisks: ${ }^{*} 10 \%$; ${ }^{* *} 5 \%$; ${ }^{* *} 1 \%$. 


\section{Conclusion}

In recent years, the increase in multi-theaters cinemas, the increase in quality with new technologies and the emergence of luxury movie theaters have made cinema a different product today than in the past. Therefore, this paper is an attempt to understand the impact of economic and other explanatory variables on cinema demand in Turkey for the 2009-2017 period. The dynamic system GMM estimation results show that the share of the domestic movie in the total number of movies and the number of cinema screens significantly affect the demand for cinema and estimates suggest that cinema attendance conforms to a rational addiction hypothesis. This study provides empirical support to rational addiction model in that cinema consumption depends future consumption.

Cinema attendance in Turkey is low compared to other European countries and varies by region. The number of movie tickets, which reached a maximum in the 1970s, could not be approached despite the increasing population. The relevance of the demand for cinema to the rational dependency theory also confirms this result. Despite the increasing number of shopping malls, the cinema sector cannot attract the audience. The validity of rational addiction model for cinema demand is controversial in the literature. In addition, the significance and influence of factors determining the demand for cinema in Turkey, are similar to other studies.

In future studies, it will be important to analyze the effect of internet use and online streaming services on the demand for cinema in order to analyze the demand for cinema market correctly.

\section{REFERENCES}

ARELLANO, M. \& STEPHEN, B. (1991). Some Tests of Specification for Panel Data: Monte Carlo Evidence and an Application to Employment Equations. Review of Economic Studies, (58)2, 277-297.

BECKER, G. S. \& MURPHY, K. M. (1988). A Theory of Rational Addiction. Journal of Political Economy, (96),4, 675-700.

BECKER, G. S., GROSSMAN, M. \& MURPHY, K. M. (1994). An Empirical Analysis of Cigarette Addiction. The American Economic Review, 84(3), 396-418.

BLANCO, V. FERNANDEZ, J. F. \& BANOS, P. (1997). Cinema Demand in Spain: A Cointegration Analysis. Journal of Cultural Economics, (21)1, 57-75.

BLUNDELL, R. \& STEPHEN, B. (1998). Initial Conditions and Moment Restrictions in Dynamic Panel Data Models. Journal of Econometrics, (87)1, 115-143.

CAMERON, S. (1999). Rational Addiction and the Demand for Cinema. Applied Economics Letters, (6)9, 617-620, DOI: 10.1080/135048599352736

COLLINS, A., HAND, C. \& RYDER, A. (2005). The lure of the multiplex? The Interplay of Time, Distance, and Cinema Attendance. Environment and Planning A 2005, (37), 483-501 DOI:10.1068/a3756

CUADRADO, M. \& FRASQUET, M. (1999). Segmentation of Cinema Audiences: An Exploratory Study Applied to Young Consumers. Journal of Cultural Economics, (23). https://doi.org/10.1023/A:1007538005838

CHMELAROVA, V. (2007). The Hausman Test, and Some Alternatives, with Heteroskedastic Data. Louisiana State University and Agricultural \& Mechanical College. DESSY, O. \& GAMBARO, M. (2009). Demand for Movies in Europe and the Effects of Multiplex Diffusion: A Panel Approach. SSRN Electronic Journal. DOI: $10.2139 /$ ssrn.1176542 
DEWENTER, R. \& WESTERMANN, M. (2005). Cinema Demand in Germany. J Cult Econ (29), 213. https://doi.org/10.1007/s10824-005-6421-0

HUBBARD, P. (2002). Screen-Shifting: Consumption, Riskless Risks and the Changing Geographies of Cinema. Environment and Planning A: Economy and Space. 34 (6), 1239-1258.

KANZLER, M. (2014). The Turkish Movie Industry Key developments 2004 to 2013. European Audiovisual Observatory.

SISTO, A. \& ZANOLA, R. (2004). Rational Addiction to Cinema? A Dynamic Panel Analysis of European Countries. Department of Public Policy and Public Choice Working Paper. (41)

TOMUR, K., KOL, İ. \& BİLAÇLI, C. (2016). Sinema Hizmetleri Sektör Raporu. Rekabet Kurumu, Ankara.

YAMAMURA, E. (2008). Socio-economic effects on increased cinema attendance: The case of Japan. The Journal of Socio-Economics (37). 2546-2555

YAMAMURA, E. (2009). Rethinking rational addictive behaviour and demand for cinema: a study using Japanese panel data, Applied Economics Letters, (16)7, 693-697, DOI:10.1080/13504850701221782

\section{Özet}

Her kesime hitap etmesi ve fiyatının diğer sanat dallarına uygun olması nedeniyle sinema, en popüler ve ulaşması en kolay sanat dallarından biridir. Zaman içerisinde sinema sektöründe de yapısal değişimler gerçekleșmiş, sinemalar alıșveriş merkezlerinde yer almaya başlamış ve hitap edilen müșteri kitlesi de değişim geçirmiştir.

Türkiye Sinema Piyasası son yıllarda bilet satışlarının artması ile beraber büyüse de 1970'li yıllarda ulaştığı potansiyelden çok uzakta kalmıştır. Sinema ile rekabet edecek teknolojilerin gelişmesi, televizyonun ve internetin yaygınlaşması sinema talebini önemli ölçüde azaltmıştır. Ayrıca Becker ve Murphy (1988) tarafından geliştirilen rasyonel bağımlılık modelinin sinemaya uyumluluğu da birçok araştırmacı tarafindan sorgulanmıştır. Rasyonel bağımlılık modeli, kısaca geçmişte tüketilen ürünlerin bugünkü ve gelecekteki tüketimi etkilemesi üzerine kurulmuştur. Bu çalışmada sinema talebini belirleyen faktörleri analiz etmek ve sinema hizmetinin rasyonel bağımlılık modeline uyumluluğu araştırmak amaçlanmıştır.

2009-2017 yılları arasındaki Türkiye'nin 81 ilinin verilerinin kullanıldığı çalışmada sabit etkiler ve dinamik panel veri modeli kullanılmıştır. Çalışmada literatürde de yaygın olarak kullandığı üzere sinema bilet fiyatları, kişi bașına düşen milli gelir, yerli filmler toplam filmler içerisindeki oranı ve sinema ekran sayısı sinema talebini etkileyen faktörler olarak ele alınmıştır. Model sonuçları yerli filmlerin ve ekran sayılarının sinema talebini olumlu etkilediği gösterilmiştir. Rasyonel bağımlılık modelinin sinema için geçerliliğinin sorgunlandığı modelde ise sonuçlar sinema talebilinin bağımlılık yapan bir mal olduğunu ortaya çıkarmıştır. Diğer bir deyişle Türkiye'de rasyonel bağımlılık modeli sinema talebi için uygulanabilmektedir. 


\section{Appendix 1}

\begin{tabular}{|l|l|l|}
\hline Variables & Description & Source \\
\hline Attendance & Number of movie tickets sold & The Turkish Statistical Institute \\
\hline Price & Real ticket price & The Turkish Statistical Institute \\
\hline GDP Per Capita & Measured in constant TL\$ & The Turkish Statistical Institute \\
\hline $\begin{array}{l}\text { Domestic Movie } \\
\text { Ratio }\end{array}$ & $\begin{array}{l}\text { Share of Domestic Movies in } \\
\text { Total Movies }\end{array}$ & The Turkish Statistical Institute \\
\hline Mall & Number of Mall & Council of Shopping Center - Turkey \\
\hline Screen & Number of Cinema Screens & The Turkish Statistical Institute \\
\hline
\end{tabular}

Table A1: Description and Sources of Data

\section{Appendix 2}

\begin{tabular}{|l|c|c|c|c|c|}
\hline Variables & Obs & Mean & SD & Min & Max \\
\hline Attendance & 234 & 1815860 & 3227298 & 4320 & 22725667 \\
\hline Price & 234 & 9,333 & 2,051 & 5,832 & 16,428 \\
\hline GDP Per Capita & 234 & 20223 & 10118 & 5275 & 65041 \\
\hline $\begin{array}{l}\text { Domestic Movie } \\
\text { Ratio }\end{array}$ & 234 & 0,438 & 0,105 & 0,230 & 0,814 \\
\hline Mall & 234 & 12,175 & 19,906 & 0 & 134 \\
\hline Screen & 234 & 82,047 & 132,177 & 13,310 & 757 \\
\hline
\end{tabular}

Table A2: Summary Statistics 